Brit. J. vener. Dis. (1966), 42, 167.

\title{
CONTACT INVESTIGATION OF MALE WEST INDIAN PATIENTS WITH GONORRHOEA*
}

\author{
BY \\ R. R. WILLCOX, F. J. G. JEFFERISS, AND E. M. NAUGHTEN \\ St. Mary's Hospital, London, W.2
}

That the male West Indian comprises a high proportion of the male patients with gonorrhoea in England and Wales is well known. The latest figures of the British Co-operative Clinical Group (1965) indicate that 22.5 per cent. of gonococcal infections in males in 1964 occurred in West Indians. The proportion vas even greater in London $(27.9$ per cent.), wh at certain individual hospitals the figures wert situch higher still.

Members of this immigrant group in a strange environment and conspicuous by their colour tend to consort with promiscuous women and in consequence are frequently infected. Moreover, their home background and basic philosophy tend to encourage promiscuity and therefore high venereal disease rates even at home, and their behavioural characteristics are maintained after arrival in the United Kingdom.

Only a relatively small percentage of male West Indians with gonorrhoea know the source of their infections. In one series of 212 male West Indian patients with gonorrhoea seen at St. Mary's in 1964 it was practicable to issue contact slips to $81(38 \cdot 2$ per cent.). As a result thirty females attended with their slips and five others of their own accord, making a total of 35 women, representing a success rate in bringing known contacts to the same clinic of $42 \cdot 2$ per cent of known contacts, but this was only 16.5 per cent. of the total number of sources. However, only fifteen women were in fact shown to have gonorrhoea (42.9 per cent. of those attending, or $7 \cdot 1$ per cent. of the men involved).

Moreover, of the 35 women traced, no less than thirty were regular consorts and likely to have been secondary contacts rather than the true sources of infection. Twelve of the fifteen cases of confirmed gonorrhoea fell in this group. Only five of the 35

- Received for publication November 10, 1965. women and only three of the fifteen proved to have gonorrhoea could be regarded as promiscuous sources. As one of the women was considered to be the source of infection of two males, the source was therefore proved for only four of the 212 men (or 1.9 per cent.). This miserable figure is likely, however, to have been somewhat higher in reality, since some of the women traced may have been responsible also for infections in other males who may have been treated in other clinics, and some of the women regarded as untraced will have attended other clinics, or indeed the same clinic, without presenting the contact slip. However, without more detailed contact investigation, knowledge of the true situation was unlikely to emerge.

\section{Present Investigation}

The findings outlined clearly indicated both the limitations of the contact slip method by itself when dealing with West Indians in London and also the desirability of gaining more detailed information of both source and secondary contacts.

A female social worker was therefore assigned to the task of contact investigation of West Indian males with gonorrhoea distinguishing particularly between suspected source contacts and secondary contacts. The present report presents the results of this contact investigation of the first 330 male patients interviewed.

The number of admitted secondary contacts of this group (i.e. from further sexual exposure within the incubation period after intercourse with the suspected donor of the infection) amounted to 86 women. After the interview the method of voluntary persuasion by the patient reinforced by a contact slip was still used to secure contacts if it was apparent that they were well known to the patient. When they were not well known, and in cases in which voluntary persuasion was not effective, visits (often 
repeated) were made. The basic data as regards sources of infection and secondary contacts are shown in Table I.

TABLE I

BASIC DATA

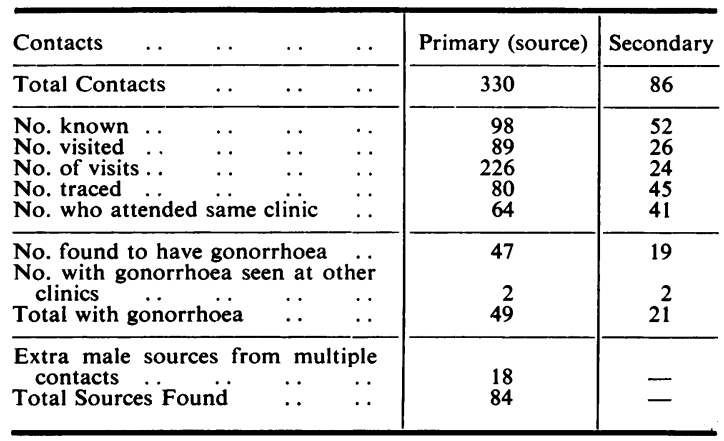

Primary (source) Contacts.-Of the $\mathbf{3 3 0}$ males with gonorrhoea, the source contacts were considered to be known in 98 (29.7 per cent. of the total). Nine attended as a result of voluntary persuasion, but visits were made to trace $89(90 \cdot 2$ per cent. of those alleged to be known), and eighty ( 81.6 per cent. of those known) proved to be traceable.

As a result of these measures, $64(80.0$ per cent. of those traced and representing 19.4 per cent. of the total numbers of men involved) actually attended the clinic. To achieve this result an average of $2 \cdot 3$ visits each to those known was necessary.

Gonorrhoea was shown to be present at the first examination in 47 (73.4 per cent. of those attending), and two sources were known to have been treated for gonorrhoea at other clinics, these were the only two sources definitely known to have attended other clinics. The number which might have been proved to be infected with gonorrhoea is likely to have been increased by repeated examinations, but epidemiological treatment was given. The 49 cases of gonorrhoea found represented 14.8 per cent. of the total sources.

However, some females were apparently responsible for multiple infections within the group, and these accounted for an additional eighteen sources. The total number of suspected sources of the $\mathbf{3 3 0}$ men, irrespective of whether gonorrhoea was proved to be present or not, was therefore 84 (25.5 per cent.). It is possible that if these results of contact investigation could be linked more closely with those of adjacent clinics this figure would be shown to be even higher. However, from the data available, while four out of five of allegedly known contacts were successfully brought to the clinic, and nearly three-quarters of them were shown to have gonorrhoea, the source contact could be regarded as known in only 29.7 per cent. of male West Indians with gonorrhoea, even after individual interviews, and in seven cases out of ten, therefore, the source was still virtually untraceable.

The sources that were traced were removed from the pool of infection by means of treatment, which was given to all either on clinico-pathological or on epidemiological grounds.

Secondary Contacts. -86 secondary contacts were admitted by the 330 men representing $26 \cdot 1$ per cent. of their total. Of these, $52(60 \cdot 1$ per cent.) were known. Many attended after voluntary persuasion and it was necessary to visit only 26 (50.0 per cent.). In all, 45 were traced ( $86 \cdot 3$ per cent. of those known or 52.3 per cent. of total). Of those traced (after an average of only 0.5 visits each), 41 ( 91.1 per cent. of those traced or 47.7 per cent. of the total) attended the clinic and nineteen $(46.3$ per cent., or $22 \cdot 1$ per cent. of the total) were found to have gonorrhoea. Two additional contacts were known to have been treated for gonorrhoea at another clinic. The total of 21 known cases of gonorrhoea represented $24 \cdot 4$ per cent. of the total number of 86 secondary contacts.

Differences in Success in Contact-tracing of Primary and Secondary Contacts.-The much greater success in locating secondary contacts was noted by Dunlop (1963), using the contact slip method. Our experience shows that this difference is no less marked if interviews are also used (Table II).

TABLE II

COMPARISON OF SUCCESS IN TRACING PRIMARY AND SECONDARY CONTACTS

\begin{tabular}{|c|c|c|c|c|}
\hline \multirow{2}{*}{ Contacts } & \multicolumn{2}{|c|}{ Primary (source) } & \multicolumn{2}{|c|}{ Secondary } \\
\hline & No. & per cent. & No. & per cent. \\
\hline Total contacts & 330 & $100 \cdot 0$ & 86 & $26 \cdot 1$ \\
\hline $\begin{array}{cccc}\text { Total contacts known } & \text { to } \\
\text { patient } & \ldots & \ldots & \ldots\end{array}$ & 98 & $29 \cdot 7$ & 52 & $60 \cdot 1$ \\
\hline \begin{tabular}{ccc} 
Known contacts & \multicolumn{2}{r}{ requiring } \\
visiting & $\ldots$ & $\ldots$
\end{tabular} & 89 & $90 \cdot 2$ & 26 & $50 \cdot 0$ \\
\hline Known contacts traced & 80 & $81 \cdot 6$ & 45 & $86 \cdot 3$ \\
\hline $\begin{array}{ccc}\text { Number of visits } & \text { to traced } \\
\text { contacts } & \ldots & \ldots\end{array}$ & 226 & $\underset{\left.\begin{array}{c}2 \cdot 3 \\
\text { each }\end{array}\right)}{\text { erage })}$ & 24 & $\begin{array}{c}0.5 \\
\text { (average) } \\
\text { each }\end{array}$ \\
\hline \begin{tabular}{cll} 
Traced contacts & \multicolumn{1}{c}{ attending } \\
same clinic & $\ldots$ & $\ldots$
\end{tabular} & 64 & & 41 & $91 \cdot 1$ \\
\hline $\begin{array}{c}\text { Total contacts } \\
\text { same clinic }\end{array}$ & 64 & $19 \cdot 4$ & 41 & $47 \cdot 7$ \\
\hline $\begin{array}{l}\text { Contacts attending shown to } \\
\text { have gonorrhoea }\end{array}$ & 47 & $73 \cdot 4$ & 19 & $46 \cdot 3$ \\
\hline
\end{tabular}


Thus, compared with source contacts, a higher proportion of the smaller number of secondary contacts were known to the patient, and these were in consequence far more readily traceable. Many fewer needed visiting and the higher proportion of those whose attendance at the clinic was secured required less than one-fifth of the average number of visits per patients. However, a lower percentage of secondary contacts than of source contacts were found to have gonorrhoea when they finally attended the clinic.

Nevertheless, the success in tracing secondary contacts was mainly achieved with wives, fiancées, and women involved in a more or less stable sexual relationship; the results with the much more important promiscuous secondary contacts were no better or even worse than were obtained in tracing primary sources of infection (Table III).

TABLE III

COMPARISON OF RESULTS IN TRACING PROMISCUOUS AND LESS PROMISCUOUS SECONDARY CONTACTS

\begin{tabular}{|c|c|c|c|c|c|c|}
\hline \multirow{2}{*}{ Contacts } & \multirow{2}{*}{$\cdots$} & & \multicolumn{3}{|c|}{ Secondary } & \multirow{2}{*}{$\begin{array}{l}\text { Primary } \\
\text { (source) }\end{array}$} \\
\hline & & & $\begin{array}{c}\text { Wives, } \\
\text { fiancées etc. }\end{array}$ & $\begin{array}{l}\text { Promis- } \\
\text { cuous }\end{array}$ & Total & \\
\hline Total & . & . & 39 & 47 & 86 & 330 \\
\hline $\begin{array}{l}\text { Traced to } \\
\text { Clinic }\end{array}$ & $\begin{array}{c}\text { Same } \\
.\end{array}$ & $\begin{array}{l}\text { No. } \\
\text { per cent. }\end{array}$ & $\begin{array}{c}34 \\
87 \cdot 2\end{array}$ & $\begin{array}{c}7 \\
14 \cdot 9\end{array}$ & $\begin{array}{c}41 \\
47 \cdot 7\end{array}$ & $\begin{array}{r}82^{*} \\
24 \cdot 8\end{array}$ \\
\hline \multicolumn{3}{|c|}{$\begin{array}{c}\text { No. proved to have } \\
\text { Gonorrhoea }\end{array}$} & 17 & 4 & 21 & 49 \\
\hline
\end{tabular}

* Same clinic only: includes women causing multiple infections.

Thus, of the 39 wives, fiancées, etc., no less than $34(87.2$ per cent.) were successfully persuaded to attend the same clinic. Of the 47 promiscuous secondary contacts, on the other hand, only 14.9 per cent. were traced, a percentage even worse than the $24 \cdot 8$ per cent. source contacts.

\section{Success or Otherwise of Control}

In this series of 330 male West Indians with gonorrhoea, 64 women who were suspected of infecting 82 men were withdrawn from the infectious promiscuous female pool. However, it is not known what fraction of the total damage these women were likely to inflict, before their infection would have been brought to light by other means than contact investigation or have been unconsciously suppressed by antibiotics given for other reasons, had already been inflicted by the time they were traced. It may be reasonable to consider 50 per cent. as a likely figure, so that the equivalent of 32 women may be regarded as having been totally withdrawn from the infectious promiscuous female pool.
Of the 86 secondary contacts, 41 were traced to the same clinic, and three-all wives or fiancées-to other clinics, and 42 were still untraced. The latter, if only for this reason, are likely to have been promiscuous and, based on the results of those who were traced, approximately one-half of these women would have had gonorrhoea. Therefore 21 women were restored to the infectious promiscuous female pool by "feedback" (Willcox, 1965). In addition, the extra "feedback" resulting from treatment failure in the $\mathbf{3 3 0}$ men must be taken into account. If this is taken at 10 per cent., there would be 33 failures. If these men consorted with promiscuous women before re-treatment in the same proportion as did the initial 330 men before the first treatment (these then consorted with 47 promiscuous women), a further 4.7 promiscuous women would have been involved. If half, again, actually became infected, an additional $2 \cdot 3$ (say 2) cases will have been restored to the infectious promiscuous female pool -making a total "feedback" of 23 cases. If to this is added the increase in the infectious female pool from the treatment failure rate in the 49 female source contacts and the four promiscuous female secondary contacts known to have been treated for diagnosed gonorrhoea, the female infectious pool will have been increased by a further $5 \cdot 3$ (say 5) cases, making a total of 28 cases in all, compared with the 32 cases considered to have been withdrawn from it.

The small gain of four cases is soon wiped out when it is considered that some men will not have owned up to all of their secondary contacts. Whether the "control" is being achieved against the resulting pressure of promiscuity in this group must therefore be regarded as extremely problematical. However, a full knowledge of attenders of promiscuous sources at other clinics if that were possible, might indicate that the balance was still on the favourable side.

\section{Summary and Conclusions}

(1) The severe limitations of the contact slip method alone for the contact-tracing of the sources of infection of male West Indians with gonorrhoea in London are outlined. The method is still useful in facilitating the attendance of secondary contacts.

(2) The results obtained by a social worker interviewing 330 West Indian patients with gonorrhoea, and by her visits to named or otherwise probably traceable contacts, are presented. Even after interview, the source of infection was considered to be known in only $29 \cdot 7$ per cent. of cases. 
(3) Allowing for women known to have caused multiple infections, the number of sources traced to the same or other clinics was $84(25 \cdot 5$ per cent. of men involved). It is possible that, if the results of contact investigations were integrated more closely between adjacent clinics, that this figure could be shown to have been higher.

(4) Contact investigation was much more successful in the tracing of secondary contacts, six out of ten of which were known to the patient. Proportionately many fewer required visiting and approximately nine out of ten of those traced attended the clinic; slightly less than one-half were in fact shown to have gonorrhoea on arrival. However, even in this group, the results were unsatisfactory, since although 87.2 per cent. of wives, fiancées, and those in a more or less stable relationship with the patient (and therefore of little significance in a consideration of epidemiological control) attended, only 14.9 per cent. of promiscuous secondary contacts (of far greater significance) were secured.

(5) The complications of these findings as regards the numbers of infections removed from the infectious promiscuous female pool and of those restored to it by "feedback" are considered in some detail. It is believed that, even with the intensive methods of contact investigation so far used in this group, the achievement of control against the current tide of promiscuity is problematical.

(6) An integrated contact investigation service involving several adjacent clinics might, however, from recognizable characteristics of contacts considered as unknown to the patient, indicate that more females are in fact being removed from the pool than can be apparent to workers in individual clinics.

\section{REFERENCES}

British Co-operative Clinical Group (1965). Brit. J. vener. Dis., 41, 237.

Dunlop, E. M. C. (1963). Brit. J. vener. Dis., 39, 109.

Willcox, R. R. (1966). "The Essence of Gonorrhoea Control. I. The Importance of 'Feed-back'." World Health Organization Working Document WHO/VDT/329.65. Acta derm.-venereol. (Stockh.), 46, 95 .
Le dépistage des contacts des hommes venant des Antilles Occidentales et souffrant de blennorragie RÉSUMÉ

(1) Les sérieuses restrictions de l'usage de la méthode de "contact slip" seulement pour retracer les contacts des sources d'infection chez les hommes venant des Antilles Occidentales et souffrant de blennorragie sont esquissées. La méthode est toutefois utile pour faciliter la visite des contacts secondaires.

(2) Les résultats obtenus par une visiteuse sociale qui a interrogé 330 malades des Antilles Occidentales souffrant de blennorragie et qui a visité les contacts nommées ou autrement facilement dépistées sont présentés. Même après ces interrogations les sources d'infection n'étaient connues que dans seulement 29,7 pour cent des cas.

(3) Déduction faite des femmes connues comme ayant causé des infections multiples, le nombre de sources découvert au même dispensaire ou à d'autres dispensaires était de 84 ( 25,5 pour cent des hommes inclus). Il est possible que si les résultats des enquêtes au sujet des contacts étaient intégrés plus intimement entre les dispensaires adjacents, ce chiffre pourrait être prouvé comme ayant été plus élevé.

(4) L'enquête pour dépister a été plus heureuse dans le cas des contacts secondaires, six contacts sur dix étaient connues du malade. Proportionnellement beaucoup moins ont nécessité une visite et à peu près neuf sur dix de celles dépistées ont visité le dispensaire, un peu moins de la moitié souffrait de blennorragie. Cependant, même dans ce groupe, les résultats n'ont pas été satisfaisants car malgré que 87,2 pour cent des épouses, fiancées et d'autres plus ou moins en contact régulier avec le malade et de ce fait n'ayant qu'une légère signification quand on considère le contrôle épidémiologique, ont rendu visite au dispensaire, seulement 14,9 pour cent des contacts secondaires qui sont d'une plus grande importance ont été dépistées.

(5) Les complications de ces observations par rapport au nombre d'infection tiré du réservoir et celui retourné au réservoir sont considérées d'une façon assez détaillée. On ne pense pas même avec les méthodes intensives de dépistage des contacts jusqu'ici employées dans ce groupe que la réalisation du contrôle contre la vague actuelle de la promiscuité soit problématique.

(6) Un service intégral de dépistage des contacts comprenant plusieurs dispensaires adjacents pourraient néanmoins indiquer que plus de femmes sont retirées du réservoir d'infection qu'il semble apparent aux observateurs de chaque dispensaire, si les caractéristiques reconnues des contacts et apparemment inconnues du malade sont prises en considération. 